\title{
Physical and Chemical Properties of Corn-Almond Cookies Affected by Mung Bean Supplementation and Source of Fat
}

\author{
Nur Aini*, Budi Sustriawan, Ervina Mela, Lisna Fuji Lestari \\ Department of Food Technology, Jenderal Soedirman University, Purwokerto 53123, Indonesia \\ *Corresponding author. Email: nur.aini@unsoed.ac.id
}

\begin{abstract}
Cookies generally contain gluten because they are made from wheat flour obtained from wheat, while there are groups that are intolerant of gluten. Patients with gluten intolerance also tend not to be able to consume casein and lactose intolerance. So, one of the innovations that can be done to make cookies gluten, casein, and lactose-free is to replace wheat flour with corn and almond flour. Corn-almond cookies produced still have a low nutritional value of protein so that supplementation is done with mung bean flour. This research aimed to find out: 1) the effect of mung bean flour supplementation on the quality of corn-almond cookies; 2) the effect of fat types on the quality of corn-almond cookies; 3) the right treatment combination between supplementation of mung bean flour and the type of fat that produces the best quality of corn-almond-based cookies. The design used in this study was Randomized Group Design (RGD). Factors studied included supplementation of mung bean flour (level of 10, 20, and 30\%) and sources of fat (margarine, Virgin Coconut Oil (VCO), and combination of margarine and VCO). Based on these factors, nine treatment combinations were obtained, which were repeated three times. Data were analyzed using variance analysis with a level of 5\% and further tests of Duncan's Multiple Range Test with a 5\% level. The best treatment was chosen by using the effectiveness index test. The results showed that supplementation of mung bean flour increased water content and reduced fat content. While the type of fat increases fat content and dissolved protein levels, and decreases the development volume. The best combination of treatments is cookies with mung bean supplementation of $10 \%$ with $100 \%$ VCO fat. Physicochemical characteristics of corn-almond cookies produced from the best treatment's combination are having a value of dissolved protein content of $2.35 \%$, fat content of $28.10 \%$, reducing sugar content of $0.21 \%$, moisture content of $2 \%$, ash content of $0.27 \%$, and volume development of $73.23 \%$.
\end{abstract}

Keywords: Corn, Cookies, Mung bean, Virgin coconut oil

\section{INTRODUCTION}

Cookies are generally made from wheat flour, which contains $80 \%$ gluten of the total wheat protein [1][2] . The gluten intolerant group cannot consume cookies from wheat flour, so they need raw materials other than wheat flour, such as corn flour. Corn flour has advantages because of the presence of functional food components such as dietary fiber, Fe, and beta-carotene [3][4]. Corn is also a source of carbohydrates that have a fairly low glycemic index so that when consumed it will not raise blood sugar. However, corn flour which is applied to the manufacture of cookies, produces a less favourable sensory aroma of cookies. To improve the sensory characteristics while increasing the nutritional value, almond flour was added.
Almond flour can be used to improve the sensory aroma of corn cookies while increasing their nutritional value [5]. Generally, gluten intolerant patients also cannot consume products containing casein, a protein in milk because it can cause allergies [6]. In addition, there is a group of sufferers who are lactose intolerant in milk. Thus, the use of almond flour can be used as an alternative to powdered milk (containing casein and lactose) in cookie processing [7]. However, almond flour is expensive, so its addition to cookies is limited.

To increase the nutritional value of cookies, especially the protein content, mung bean flour can be added in the manufacture of cookies. Mung beans contain high protein by $24 \% \mathrm{db}$ and important mineral sources, including calcium and phosphorus [8]. Thus, the addition 
of mung bean also aims to supplement the low protein of corn-almond cookies.

In making cookies, it is necessary to add fat/oil to form a crunchy texture and increase flavour [9]. The type of fat that is usually used is margarine which has a solid texture, bright yellow colour, and does not melt easily. Many types of fat other than margarine can be added in making cookies. Virgin Coconut Oil (VCO) is a type of oil that has a high lauric acid content compared to other vegetable oils. VCO contains 50\% lauric acid and 7\% caprylic acid [10]

This study aims to: 1) determine the effect of mung bean flour supplementation on the physicochemical properties of corn-almond flour-based cookies; 2) determine the effect of fat type on the physicochemical properties of corn-almond flour-based cookies; 3) determine the right combination of treatment between mung bean flour supplementation and the type of fat that produces corn-almond flour-based cookies with the best physicochemical properties.

\section{MATERIALS AND METHOD}

The main ingredients used for making cookies are yellow corn flour from Purbalingga Regency, "Khas Jaya Nusantara" almond flour from Tangerang Banten, "Healthy" mung bean flour from Sukamanunggal Surabaya, margarine, VCO "Mutia", refined sugar "Gulaku", baking powder, eggs and salt.

The ingredients for making cookies include corn flour (67\%), almond flour (33\%), mung bean flour (according to the percentage of supplementation), fat ( $45 \%$ of total flour), eggs ( $20 \%$ of total flour), sugar ( $40 \%$ of total flour), baking powder ( $1 \%$ of total flour) and salt $(0.5 \%$ of total flour). The method of making cookies refers to the method of [11] with modification of ingredients. Making cookies begins with mixing sugar and fat for 3 minutes to form a cream. Then add eggs and mix until homogeneous, then add corn flour, almond flour, mung bean flour, salt, and baking powder. Mixing is done until all the ingredients are homogeneous, followed by moulding. The next stage is roasting for 20 minutes at $170^{\circ} \mathrm{C}$. Cookies that have been cooked are then cooled to room temperature and packaged using plastic until analysed. Analysis was conducted on the volume expansion [12], moisture content using gravimetric method [13], fat content using extraction method[13], soluble protein content, ash content was using thermogravimetric [13], and reducing sugar using ICUMSA method [14].

This research is an experimental study with a factorial randomized block design. The factors studied were the percentage of mung bean flour supplementation consisting of 3 levels $(10,20$ and $30 \%)$ and the type of fat consisting of 3 rates (margarine, $\mathrm{VCO}$, combination of margarine and VCO (1:1)). These factors were then arranged in a factorial manner so that 9 treatment combinations were obtained, and were repeated 3 times.

The data obtained were analyzed using analysis of variance ( $F$ test) at the 5\% level. If the results of the analysis have a significant effect, then proceed with Duncan's Multiple Range Test (DMRT) with a level of $5 \%$. Based on the results of physicochemical analysis, the determination of the product with the best cookie formulation was analyzed using an effectiveness index.

\section{RESULTS AND DISCUSSION}

Table 1 shows that mung bean supplementation has a very significant effect on water content, significantly affects fat content, and has no significant effect on ash content, reducing sugar content, protein content, and expansion volume. Meanwhile, different types of fat had a significant effect on fat content, protein content, and volume of expansion and had no significant effect on water content, ash content, and reducing sugar content. The combination of mung bean supplementation and the type of fat showed no significant effect on all variables.

Table 1. The effect of mung bean flour substitution and the type of fat on the characteristics of cookies

\begin{tabular}{|c|c|c|c|c|}
\hline No & Variable & $\begin{array}{l}\text { Type } \\
\text { of fat }\end{array}$ & $\begin{array}{c}\text { Mung bean } \\
\text { supplementation }\end{array}$ & Interaction \\
\hline 1. & $\begin{array}{l}\text { Moisture } \\
\text { content }\end{array}$ & $* *$ & ns & ns \\
\hline 2. & $\begin{array}{l}\text { Ash } \\
\text { content }\end{array}$ & ns & ns & ns \\
\hline 3. & $\begin{array}{l}\text { Fat } \\
\text { content }\end{array}$ & $*$ & $*$ & ns \\
\hline 4. & $\begin{array}{l}\text { Reducing } \\
\text { sugar } \\
\text { content }\end{array}$ & ns & ns & ns \\
\hline 5. & $\begin{array}{l}\text { Soluble } \\
\text { protein } \\
\text { content }\end{array}$ & ns & $*$ & ns \\
\hline 6. & $\begin{array}{l}\text { Expansion } \\
\text { volume }\end{array}$ & ns & $*$ & ns \\
\hline
\end{tabular}

\subsection{Moisture Content}

Mung bean flour moisture content is $6.25 \%$ [7] and its supplementation had a significant effect on the moisture content of cookies, while the type of fat and the combination of them did not have a significant effect. Supplementation with 30\% mung bean flour resulted in cookies with the highest moisture content of $2.98 \%$, but it was not significantly different from $20 \%$ 
supplementation which resulted in $2.93 \%$ moisture content in cookies. The lowest water content was found in $10 \%$ mung bean flour supplementation, which was $2.16 \%$. The moisture content of cookies increases with the increase in the amount of mung bean flour (Fig 1).

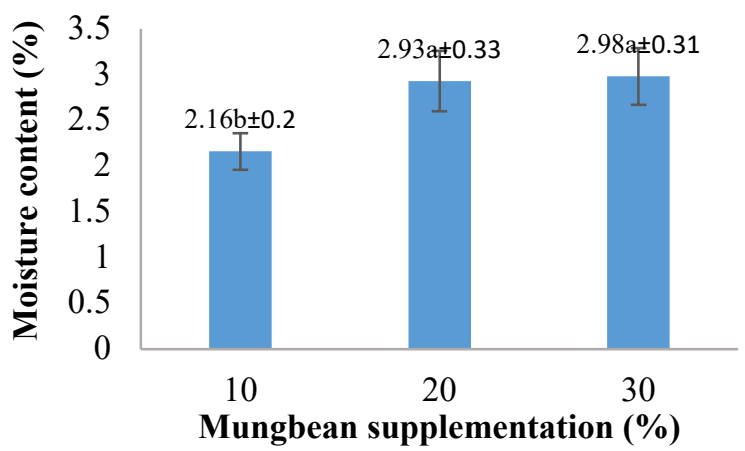

Figure 1. Effect of mung bean supplementation to moisture content of cookies

The result in this study was in compliance to Widjajaseputra et al. (2019), showing that moisture content increased following the increase of mung bean flour content [8]. The increase in moisture content was due to an increase in the amount of protein due to an increase in the amount of mung bean flour. The roasting process results in protein denaturation, where large protein molecules exposed to heat will form a compact network in the form of a matrix [9]. The matrix causes water to be trapped in these protein molecules and cannot escape.

Protein has two types of, that is both hydrophobic and hydrophilic [15]. Protein on mung bean flour, which can be as $22.05 \%$, has more hydrophilic bonds, which has a high-water binding power, so that if the water content of protein in the high mung beans, then allow these cookies water content is also high[16]. The higher the hydrophilic proteins in a food will cause an increase in solubility in liquids because the more hydrophilic group (e.g., lysine, tryptophan, asparagine, glutamine, and histidine) that causes increased water binding capacity [17]

The moisture content of cookies is also influenced by the content of amylose and amylopectin in mung bean flour. The amylose content of mung bean flour is $33 \%$, and amylopectin is $67 \%$ [18]. Amylose is easy to absorb and release water. Meanwhile, amylopectin has the property of being difficult to absorb water but the water will be retained when it is absorbed [19][20]. So, the more the amount of mung bean flour added, the higher the moisture content value.

The moisture content of cookies can be affected by the interaction between starch and protein. The decrease in water content can occur due to the bond between starch and protein which causes water to not be bound to the maximum. Hydrogen bonds formed between molecules of starch and water will be reduced by the interaction between starch and protein [20],[21]. According to SNI (01-2973-2011), the water content of the cookies maximum of $5 \%$, so these cookies already fulfil the quality requirements of cookies by the Indonesian National Standard.

\subsection{Ash Content}

Ash content is a value that indicates the amount or total minerals contained in a product. Mung bean supplementation and different types of fat had no significant effect on the ash content of cookies. The ash content of corn-almond cookies is $0.27-1.17 \%$, as seen in Fig 2. Supplementation of mung beans $10 \%$ and the use of margarine resulted in cookies with the lowest ash content of $0.27 \%$.

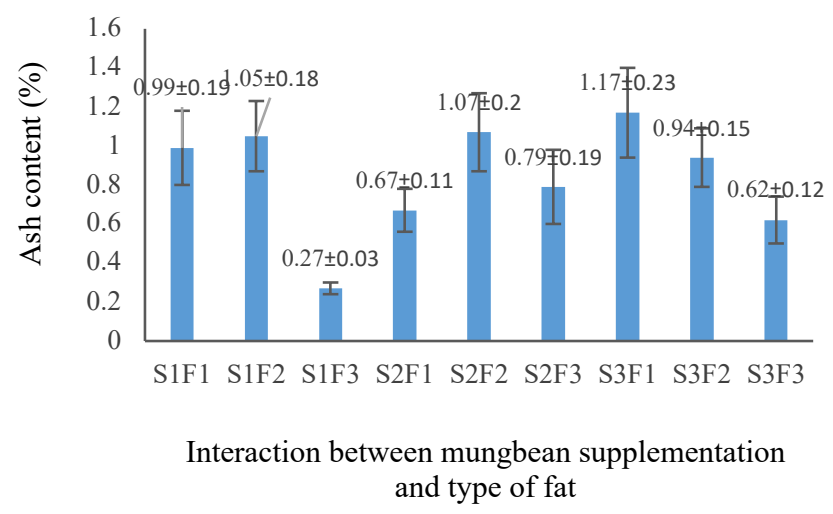

Figure 2. Ash content of corn-almond cookies with soy flour supplementation and types of fat

The higher the supplementation of mung bean flour, the higher the ash content of the product [22]. The increase was because beans had a high ash content of $3.07 \%$ compared to) corn flour $(0.13 \%)$. Mung beans are a source of minerals calcium, phosphorus and iron as 223, 319 and $7.5 \mathrm{mg}$ every $100 \mathrm{~g}$. The low ash content of corn flour is due to the separation of the germ in its manufacture, where the germ contains $75 \%$ of minerals in corn.

According to the Indonesian National Standard (SNI) (01-2973-2011) the maximum ash content for cookies is $1.5 \%$. Therefore, the ash content of these cookies has met the requirements of the Indonesian National Standard.

\subsection{Fat Content}

Mung bean supplementation and differences in fat sources had a significant effect on the resulting cookies, but the combination of the two had no significant effect. The highest fat content of $26.2 \%$ was produced in $10 \%$ mung bean flour supplementation, while the lowest at $23 \%$ was found in $30 \%$ supplementation (Figure 3 ). 
Increased mung bean supplementation resulted in a decrease in the fat content of cookies. These results are in compliance with Agung et al. (2018), which showed that the substitution of mung bean flour could reduce the fat content of bagea [23]. This is because mung bean flour has a low fat content. According to Widjajaseputra et al. (2019), the fat content in mung beans is $1.2 \%$ [8]. Corn flour has a higher fat content than mung beans, which is $3.80 \%$ [3]. Therefore, the greater the added mung bean flour, the lower the fat content.

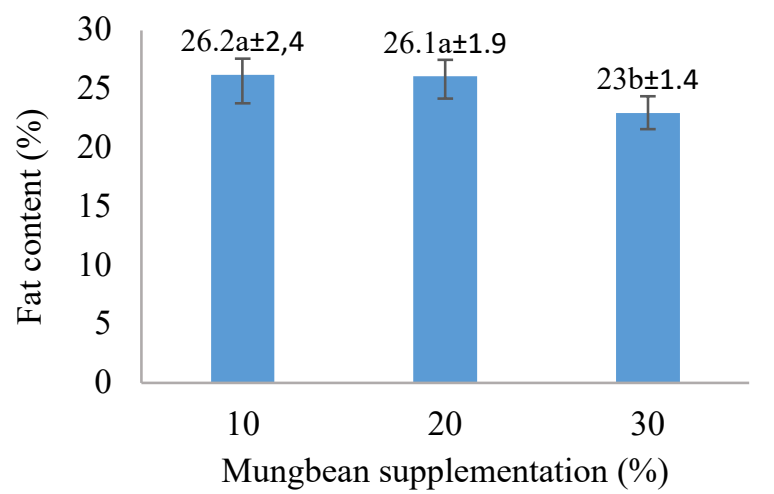

Figure 3. Effect of mung bean supplementation to fat content of cookies

The highest fat content is found in cookies that use VCO, which is $26.8 \%$, while the lowest fat content $(23.8 \%)$ is produced by using margarine. The higher the proportion of $\mathrm{VCO}$ in the manufacture of cookies, the higher the fat content of cookies. This is due to the difference in the amount of fat in margarine and VCO. VCO contains $98 \%$ fat, while margarine contains $80 \%$ fat. This resulted in the addition of more VCO in the manufacture of cookies, the fat content increased as can be seen in Figure 4.

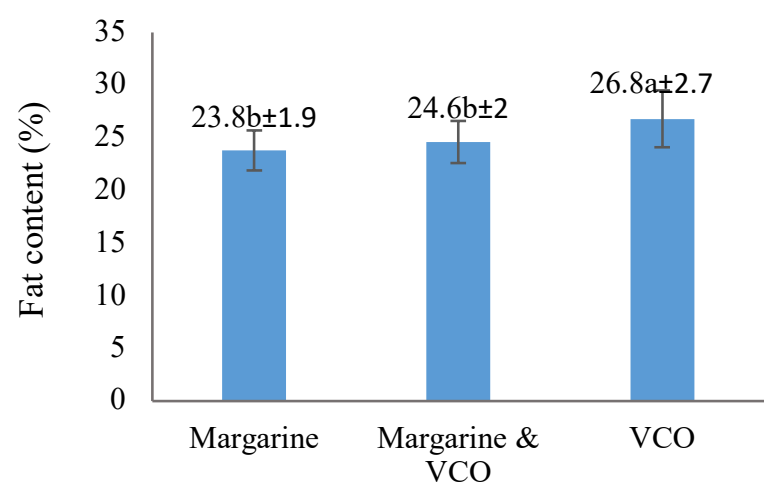

Source of fat

Figure 4. Fat content of cookies was affected by fat source

The fat content of cookies is quite high, but the fat contained in margarine is free of trans fat, while VCO is classified as a healthy oil because almost $50 \%$ of its fatty acids are medium chain, so it is easily absorbed. According to Lee et al. (2018), medium chain fatty acids have an advantage over long chain fatty acids is that they are easier to digest and absorb [24]. Medium chain fatty acids can be directly digested in the intestine without hydrolysis and enzymatic processes. So, in this study, although the fat content of cookies has a higher proportion of $\mathrm{VCO}$, it is more easily absorbed and digested by the body.

One of the factors that can affect the fat content of cookies is the type of flour, because each flour has a different oil absorption capacity. Oil absorption is related to protein structure, where the minor components of gluten (lipids and polysaccharides), the proportion of different gluten protein groups and the balance of hydrophilic gluten properties cause differences in oil absorption capacity [25][26]. According to Fairouz et al. (2018), the high absorption of oil is due to the protein content and fat content [27]. The greater the fat or protein content, the greater the oil absorption capacity.

According to El Waseif and Badr (2018), oil absorption is also influenced by amylose content because it has the ability to form complexes with oil (lipids) in the form of amylose-lipids [28]. The higher the amylose content, the higher the oil absorption capacity. The high fat content of cookies affects the resulting texture, especially the crunchiness [29][30]. However, high fat content can also cause the shelf life of cookies to be shorter due to fat oxidation so that cookie packaging needs to be considered to prevent fat oxidation.

These cookies have almost the same fat content, compared to the $25.3 \%$ fat content of wheat flour cookies [31] but are higher than cookies from sorghum [32] . This is due to the use of corn flour that has $84 \%$ oil absorption capacity compared to $1.5 \%$ of wheat flour [25], [33]. This is due to the difference in amylose content, where corn flour has a higher amylose content $(30 \%)$ compared to wheat flour $(25 \%)$. According to Widjajaseputra et al. (2019), mung bean flour used for supplementation has an amylose content of 33\% [8]. These differences, so that it can affect the amount of fat content contained in corn-almond cookies. The fat content of cookies is in accordance with the fat content of Indonesian National Standard (SNI 01-2973-2011) which is at least $5 \%$.

\subsection{Reducing Sugar}

Mung bean flour supplementation, the use of types of fat, and the combination of the two did not have a significant effect on the reducing sugar content of cookies. The increasing supplementation of mung bean flour and the proportion of $\mathrm{VCO}$ in the processing of corn-almond cookies causes the value of reducing sugar content to tend to increase. According to Widjajaseputra et al. (2019), mung bean flour has reduced sugar content as much as $6.85 \%$ [8]. 


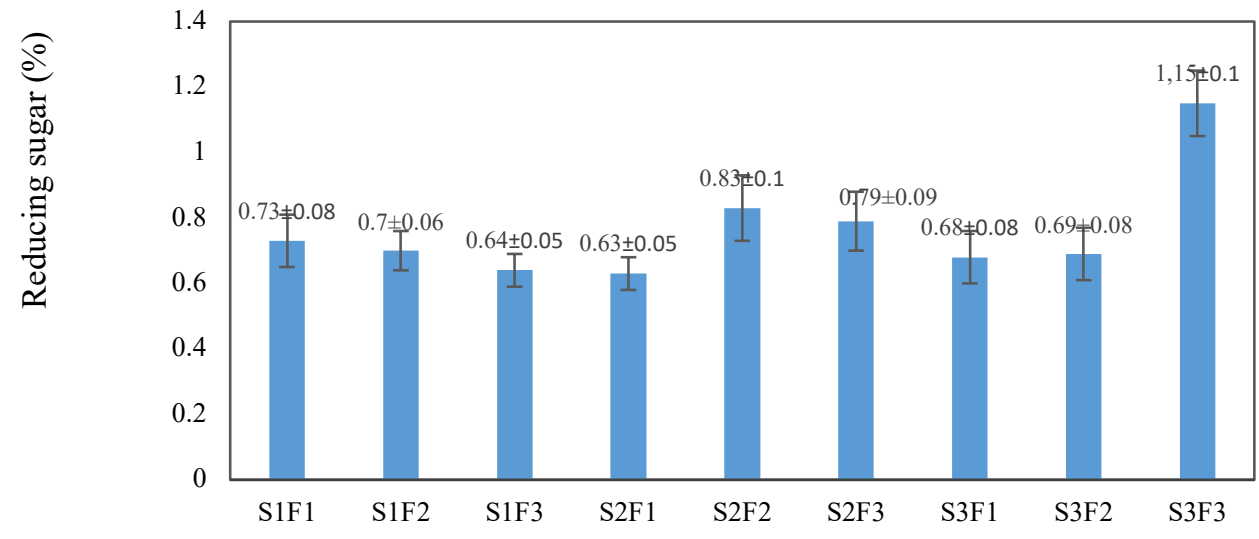

Interaction of mungbean supplementation and type of fat

Figure 5. Reducing sugar of corn-almond cookies with soy flour supplementation and types of fat

The reducing sugar content in cookies mostly comes from sugar in the ingredients. In this study the sugar used is granulated sugar which is sucrose. The sucrose content in sugar is $99.3 \%$ or more. Heating sucrose causes sucrose to break down into glucose and fructose which is called invert sugar. The increase in reducing sugar levels was due to the inverse process of sucrose into reducing sugar and the inversion process increased in line with the increase in the sucrose content, in addition heating also encouraged hydrolysis of sucrose into reducing sugars, glucose and fructose [34]. According to Indonesia's National Agency of Drug and Food Control, a product can be said to be a low-sugar product if it contains no more than 5\% sugar. Referring to these requirements, the corn-almond cookies are included in the low-sugar product.

\subsection{Soluble Protein}

The type of fat has a significant effect on the soluble protein content of cookies. Increasing the amount of $\mathrm{VCO}$ in the cookie formulation increased the soluble protein content of cookies. Cookies with the addition of $\mathrm{VCO}$ as a source of fat had the highest soluble protein content, which was $2.57 \%$, as shown in Figure 6.

The increase in soluble protein content is influenced by the reaction between protein and fat in the process of making cookies. Protein will coagulate by heating so that during the roasting process, more protein will coagulate [34][35]. During the coagulation process, fat globules will be formed which can bind proteins and peptides in it so that it can increase protein levels. So that if the VCO or margarine is increased as a source of fat, it will increase the bound protein and also increase the dissolved protein content. The increase in VCO can increase the dissolved protein content because the fat content in VCO is higher than margarine. VCO contains $98 \%$ fat content, while margarine contains approximately $80 \%$ fat. So, the greater the fat content, the greater the amount of fat that can bind protein.

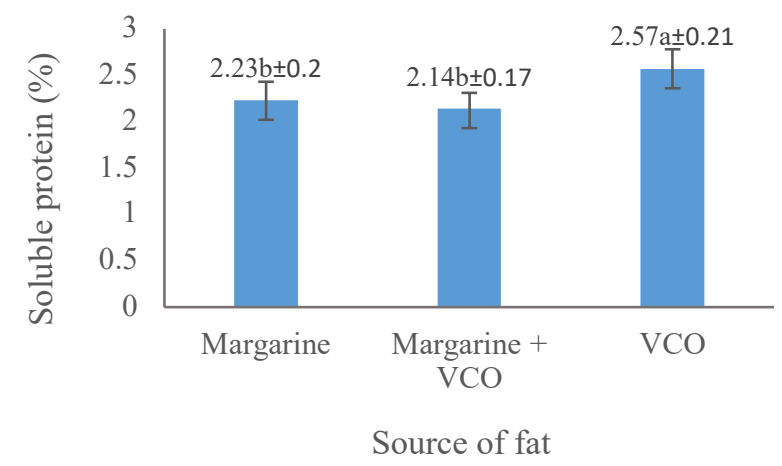

Figure 6. The effect of source fat on the soluble protein of cookies

The protein content in margarine is lower than VCO. Margarine has a protein of $0.6 \%$, while $\mathrm{VCO}$ is $1 \%$. The process of making VCO involves breaking the emulsion using enzymes to separate the oil from the coconut milk. According to Amin et al. (2017), the breakdown of coconut milk emulsions can occur in the presence of proteolytic enzymes that catalysed protein breakdown reactions by hydrolysing their peptide bonds into simpler compounds [10]. Proteolytic enzymes catalysed peptide bonds in proteins into simpler compounds such as dipeptides and amino acids. Protein hydrolysis that occurs can cause proteins that are initially insoluble to become soluble proteins.

\subsection{Expansion Volume}

The volume of cookie development is closely related to the ingredients or formulation of cookies used. Different types of fat had a significant effect on the 
volume of cookie development, while supplementation with mung bean flour and the combination of the two had no significant effect. As the number of VCOs added increases, the development volume decreases as seen in Figure 7. Cookies with the addition of $100 \%$ margarine had the highest expansion volume, namely $81.2 \%$, while cookies with the addition of $100 \%$ VCO had the lowest expansion volume, namely $63.6 \%$ (Figure 7 ). One of the factors that affect the volume of cookies development is moisture content.

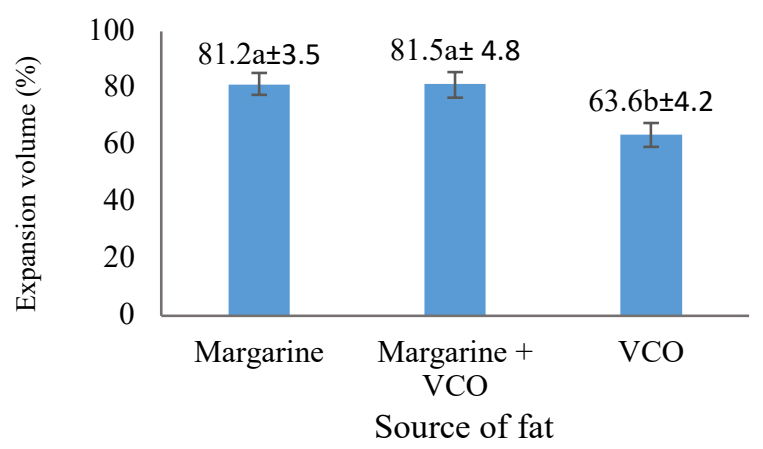

Figure 7. The effect of source fat on the soluble protein of cookies

The decreases in the volume of development can be due to the very small amount of liquid available in cookie dough [24]. This causes less interaction between water and gluten to form a gluten network that can withstand the expanding gases during the baking process. This is due to the low VCO water content as stated in the VCO composition, which is $0.1 \%$. Margarine has a higher moisture content maximum of $16 \%$. At the time of making cookies, the dough added with VCO turned out to be more viscous or denser and easier to shape than the dough added with margarine. According to Bolarinwa et al. (2019) cookie dough that has a more viscous consistency has a tendency to expand less when baked [34].

The expansion volume is influenced by protein content, amylopectin content and fat content [34], [36]. This is because the protein is denatured, causing the cookies to be difficult to expand and hard. Starch granules without protein will break easily and the amount of water that enters the starch granules will be more so that the development of starch will increase. This is in line with Mancebo et al. (2016) who stated that the volume of cookie development was also caused by the addition of high fat in the formula [37]. The proportion of added fat in the cookie formula affects the bond development of gluten.

Fat in cookies will change the texture, taste, and flavour of the product. The addition of fat can also cause interactions with starch granules and break hydration so that the increase in viscosity of the material becomes low. The mechanism of inhibition is that fat will form a layer on the outside of the starch granules and at the same time inhibit the penetration of water into the granules. Less water penetration will result in high gelatinization and will form cookies that are less fluffy with a denser / compact texture. According to Bolanriwa et al. (2019), if too much fat is added, it can cause cookies to widen and break easily, while too little fat makes the texture of the pastry hard and less fluffy [34]. The baking process also affects the swell ability of cookies, because when roasting the water bound in the starch granules is released during oven at a certain temperature so that the water evaporates and the steam formed will push the gel network out and cookies will develop.

Corn flour also plays a role in the development of cookies. According to Aini et al. (2016), corn flour contains amylose and amylopectin, this amylopectin content can affect the volume of cookie development, where amylopectin has a structure that easily absorbs water and water will be retained in it if it is absorbed [25]. The existence of these properties will make the starch structure will be hollow when baked due to evaporation of water from the starch molecules so that the volume of cookies will be larger.

The main component in flour that affects the texture of cookies is protein [34],[38]. The protein contained in flour can form gluten when added to water. Gluten can make dough elastic and able to hold gas. If the amount of gluten in the dough is small, the dough is less able to hold gas, so the pores that form in the dough are also small. As a result, the dough does not rise properly. The flour used in this study did not contain gluten, so development was lacking. This is in line with Jan et al. (2018) which states that cookies do not require basic ingredients that affect the swelling power so that cookies can be made using flour containing $<1 \%$ gluten [39].

Cookies have a dough that is less elastic and less stretchy [40][41]. The amount of fat and sugar in the dough gives the dough plasticity and unity with no or very little gluten network formation. Cookies do not require volume expansion like wet cakes and rolls, but must be crispy, not absorbing water quickly, not hard and not crumbling easily. These properties are in accordance with the physicochemical and functional properties of corn flour.

\subsection{Selected Formula}

The 10\% mung bean flour supplementation and the use of VCO produced cookies with the best physicochemical properties. The combination has soluble protein of $2.35 \%, 28.10 \%$ fat content, $0.21 \%$ reducing sugar, 2\% moisture content, $0.27 \%$ ash content, and $73.23 \%$ expansion volume. The moisture and fat content of these corn cookies were higher than those of sago cookies that used VCO, while the ash content was lower. 
According to Barlina et al. (2012), sago cookies that use VCO have a water content of $0.25 \%$, ash content of $1.35 \%$, and fat content of $19.68 \%$ [42]. This is influenced by the use of sago flour and wheat flour, where sago flour has $14 \%$ water content, $0.2 \%$ fat and $1.4 \%$ ash content, meanwhile wheat flour has $12 \%$ water content and $1.4 \%$ fat. The water and fat content are lower than corn and almond flour, while the ash content is higher.

According to Ratnasari and Yunianta (2015), cookies added with $10 \%$ mung bean flour have a protein content of $10.52 \%$, a fat content of $17.52 \%$, a water content of $6.41 \%$, and an ash content of $0.67 \%$ [43]. When compared with corn-almond cookies in this study, the fat content value is smaller but the ash content and water content are higher. Meanwhile, Yuliatmoko and Satyatama (2012) state that Lampung taro cookies supplemented with $10 \%$ mung bean flour in a previous study are shown to have a water content of $3.9 \%$, ash content of $1.32 \%$, fat content of $24.56 \%$, and protein content of $8.07 \%$ [44]. When compared with almond corn cookies with mung bean supplementation as much as $10 \%$, the water content and ash content values of cornalmond cookies were lower than those of taro Lampung cookies. Meanwhile, the fat content of corn-almond cookies was higher. This is influenced by differences in ingredients.

Agung et al. (2015) states that biscuits with the addition of $15 \%$ mung bean flour were the most preferred, which had $1.5 \%$ ash content, $7.12 \%$ water, $14.29 \%$ fat, and $3.39 \%$ protein content [23]. If seen from these results, the corn-almond cookies have a value of ash and lower water levels, but it has a higher fat content value. Based on a comparison with some cookies that are added or supplemented with mung beans and the use of $\mathrm{VCO}$, it turns out that the cookies in this study have several advantages in terms of their physicochemical variables. Cookies produced in this study have also fulfilled Indonesian National Standard.

\section{CONCLUSION}

Increased mung bean supplementation in cornalmond cookies improves moisture content and reduces fat content. Different fat sources affect fat content, soluble protein and expansion volume, and the best is VCO. The product with the best formulation is cookies $\mathrm{d}$ with $10 \%$ mung bean flour supplementation and uses VCO. These cookies have a soluble protein of $2.35 \%$, $28.10 \%$ fat, $0.21 \%$ reducing sugar, $2 \%$ water content, $0.27 \%$ ash, and $73.23 \%$ expansion volume.

\section{ACKNOWLEDGMENTS}

This research was funded by Directory of Research and Community Service through Basic Research 2021 with the contract number 117/SP2H/LT/DRPM/2021

\section{REFERENCES}

[1] H. Bourekoua, R. Różyło, L.Benatallah, AWójtowicz, G Łysiak, M.N. Zidoune, A. Sujak, Characteristics of gluten-free bread: Quality improvement by the addition of starches/hydrocolloids and their combinations using a definitive screening design, Europeuan Food Research Technology 244 (2018) 345-54. DOI:https://doi.org/ 10.1007/s00217-017-2960-9

[2] G. Altındağ, M. Certel, F. Ere, U.K. İlknur, Quality Characteristics of gluten-free cookies made of buckwheat, corn, and rice flour with/without Transglutaminase, Food Science Technology International $21 \quad$ (2015) 213-20. DOI: https://doi.org/ 10.1177/1082013214525428

[3] N. Aini, V. Prihananto, G. Wijonarko, B Sustriawan, M. Dinayati, F. Aprianti, Formulation and characterization of emergency food based on instan corn flour supplemented by instan tempeh (or soybean) flour, International Food Research Journal 25 (2018) 287-292.

[4] R. Moreira, F. Chenlo, S. Arufe, S.N. Rubinos, Physicochemical characterization of white, yellow and purple maize flours and rheological characterization of their doughs, Journal Food Science Technology 52 (2015) 7954-7963. DOI: https://doi.org/10.1007/s13197-015-1953-6

[5] M.L. Martínez, M.A. Marín, R.D. Gili, M.C. Penci P.D. Ribotta, Effect of defatted almond flour on cooking, chemical and sensorial properties of gluten-free fresh pasta, International Journal Food Science Technology 52 (2017) 2148-2155. DOI: http://doi.wiley.com/10.1111/ijfs.13493

[6] M.M.A. Aly, H.A. Seleem, Gluten-free flat bread and biscuits production by cassava, extruded soy protein and pumpkin powder, Food Nutrition Science 6 (2015) 660-674. DOI: https://doi.org/10.4236/fns.2015.67069

[7] A.M. Mori, R.V. Considine, R.D. Mattes, Acute and second-meal effects of almond form in impaired glucose tolerant adults: a randomized crossover trial, Nutrition Metabolism 8 (2011) 6. DOI: https://doi.org/6 10.1186/1743-7075-8-6

[8] A.I. Widjajaseputra, T.E.W. Widyastuti, C.Y. Trisnawati, Potency of mung bean with different soaking times as protein source for breastfeeding women in Indonesia, Food Research 3 (2019) 501505 DOI: https://doi.org/10.1186/1743-7075-8-6

[9] A. Chauhan, D.C. Saxena, S. Singh, Total Dietary Fibre and Antioxidant Activity of Gluten Free Cookies Made from Raw and Germinated Amaranth (Amaranthus spp.) flour, LWT - Food Science Technology 63 (2015) 939-945. DOI: https:/doi.org/10.1016/J.LWT.2015.03.115. 
[10] Z.A. Amin, S.P. Koh, N.S.A. Hamid, C.P. Tan, K. Long, New coating material for producing Virgin Coconut Oil (VCO) microcapsules, Food Research 1 (2017) 15-22. DOI: https://doi.org/10.26656/fr.2017.1.003

[11] J.A. Kurniawan, R.B. Anandito, S. Siswanti, Karakteristik fisik, kimia dan sensori cookies berbahan dasar tepung komposit uwi, koro glinding dan tepung terigu, Jurnal Teknologi Hasil Pertanian XI (2018) 20-32.

[12] B.O. Tavares, E.P. da-Silva, V.S.N. da-Silva, M.S. Junior, E.I. Ida, C. Damiani, Stability of gluten free sweet biscuit elaborated with rice bran, broken rice and okara, Food Science Technology 36 (2016) 296-303. DOI: https://doi.org/10.1590/1678457X.0083

[13] AOAC, Official methods of analysis of the Association of Official Agricultural Chemists, International Journal Associaton Official Agriculture Chemical 41 (2005) 12.

[14] M.A.A. Gasmalla, R. Yang, I. Amadou, X. Hua, Nutritional composition of stevia rebaudiana bertoni leaf: effect of drying method, Tropical Journal Pharmaceutical Research 13 (2014) 61-65 https://doi.org/10.4314/tjpr.v13i1.9

[15] M. Hosseinzadeh, A. Moayedi, H.C. Moghadas, K. Rezaei, Nutritional, anti-nutritional, and antioxidant properties of several wild almond species from Iran, Journal Agriculture Science Technology 21 (2019) 369-380.

[16] J.H. Lee, J.K. Jeon, S.G. Kim, S.H. Kim, T. Chun, J.Y. Imm, Comparative analyses of total phenols, flavonoids, saponins and antioxidant activity in yellow soy beans and mung beans, International Journal Food Science and Technology 46 (2011) 2513-2519. DOI: https://doi/10.1111/j.13652621.2011.02775.x.

[17] J. Buggenhout, K. Brijs, J.A. Delcour, Impact of processing conditions on the extractability and molecular weight distribution of proteins in parboiled brown rice, J. Cereal Science 58(1) (2013) 8-14. DOI: https://doi.org/10.1016/j.jcs.2013.05.002.

[18] R. Hardiyanti, S. Suharman, M.Z.E. Sinaga, I.P. Mahendra, A. Hartanto, Physicochemical characteristics of modified starch granules from Durio Zibethinus Murr. var. Bintana, AIP Conference Proceeding 2342, (2021). DOI: https://doi.org/10.1063/5.0045547.

[19] H. Zhang, X. Zhou, T.Wang, X. Luo, L. Wang, Y. Li, R. Wang, Z. Chen, New insights into the action mode of amylosucrase on amylopectin, International Journal Biology Macromoleculer 88 (2016) 380-384. DOI: https://doi.org/10.1016/j.ijbiomac.2016.04.007.
[20] A.A. Mohamed, Applications of native and modified corn starch (a review), Journal Saudi Society. Food Nutrition 13(1) (2020) 24

[21] N.L. Vanier, D.R.Z. Elessandra,V.Z. Pinto, B. Klein, F.T. Botelho, A.R.G. Dias, M.C. Elias. Physicochemical, crystallinity, pasting and morphological properties of bean starch oxidised by different concentrations of sodium hypochlorite, Food Chemistry 131(4) (2012) 1255-1262. DOI: https://doi.org/10.1016/j.foodchem.2011.09.114.

[22] I.M.D.P.Rianta, P.T. Ina, I.W.R. Widarta, Pengaruh perbandingan Mocaf (Modified Cassava Flour) dengan tepung kacang hijau (Vigna radiata) terhadap karakteristk Tuile, Jurnal Ilmu dan Teknologi Pangan 8(3) (2019) 293, 2019, DOI: https://doi.org/10.24843/itepa.2019.v08.i03.p08.

[23] A.P. Agung, T. Tamrin, S. Rejeki, Kajian pengembangan tepung kacang hijau (Vigna Radiata $L$ ) sebagai bahan sustitusi bagea untuk memenuhi angka kecukupan zat besi (Fe) remaja putri, Jurnal. Sains dan Teknologi Pangan 3(6) (2018) 17241735.

[24] Y.Y. Lee, TK. Tang, E.T. Phuah, N.A.A. Karim, N.B.M. Alitheen, C.P. Tan, I.S.A. Razak, O.M. Lai, Structural difference of palm based Medium- and Long-Chain Triacylglycerol (MLCT) further reduces body fat accumulation in DIO C57BL/6J mice when consumed in low fat diet for a mid-term period, Food Research International 103(10) (2017) 200-207.

DOI: https://doi.org/10.1016/j.foodres.2017.10.022.

[25] N. Aini, G. Wijonarko, B. Sustriawan, Physical, chemical, and functional properties of corn flour processed by fermentation, Agritech 36(2) (2016) 160-169, DOI: https://doi.org/10.22146/agritech.12860.

[26] N. Aini, P. Hariyadi, Gelatinization properties of white maize starch from three varieties of corn subject to oxidized and acetylated-oxidized modification, International Food Research Journal 17(4) (2010) 961-968.

[27] D. Fairouz, B. Hayat, B. Leila, N.Z. Mohammed, Effect of pregelatinized corn and rice flour on specific volume of gluten-free traditional Algerian bread KhobzEddar using central composite design, African Journal Food Science 12(10) 2018 272282. DOI: https://doi.org/10.5897/AJFS2017.1666.

[28] M. El-waseif, Using Egyptian caper seeds oil ( Capparis spinosa $L$ ) as a natural antioxidant to improving oxidative stability of frying oils, World Journal Dairy Food Science 13(2) (2018) 18-30. DOI:

https://doi.org/10.5829/idosi.wjdfs.2018.18.30.

[29] E.P. da Silva, H.H. Siqueira, C. Damiani, E.V.B. Vilas-Boas, Physicochemical and sensory 
characteristics of snack bars added of jerivá flour (Syagrus romanzoffiana), Food Science and Technology 36(3) (2016) 421-425. DOI: https://doi.org/10.1590/1678-457X.08115.

[30] G. Giuberti, G. Rocchetti, S. Sigolo, P. Fortunati, L. Lucini, A. Gallo, Exploitation of alfalfa seed (Medicago sativa L.) flour into gluten-free rice cookies: Nutritional, antioxidant and quality characteristics, Food Chemistry 239 (2018) 679687.

DOI: https://doi.org/10.1016/j.foodchem.2017.07.004.

[31] M. Taufik, Formulasi cookies berbahan tepung terigu dan tepung tempe dengan penambahan tepung pegagan, Jurnal Agroindustri Halal 5(1) (2019) 9-16. DOI: https://doi.org/10.30997/jah.v5i1.1582.

[32] I. Bolanriwa, A.O. Abioye, J. Adeyanju, Z.O. Kareem, Production and quality evaluation of biscuits produced from malted sorghum-soy flour blends, Journal Advanced Food Science Technology 3(3) (2016) 107-113.

[33] H. Nawaz, M. Aslam, T. Rehman, R. Mehmood, Modification of emulsifying properties of cereal flours by blending with legume flours, Asian Journal Dairy Food Research I (2021) 1-6. DOI: https://doi.org/10.18805/ajdfr.dr-223.

[34] I.F. Bolarinwa, P.T. Lim, M. Kharidah, Quality of gluten-free cookies from germinated brown rice flour, Food Research 3(3) (2019) 199-207. DOI: https://doi.org/10.26656/fr.2017.3(3).228.

[35] B. Filipčev, A. Mišan, B. Šarić, O. Šimurina, Sugar beet molasses as an ingredient to enhance the nutritional and functional properties of gluten-free cookies, International Journal Food Science Nutrition 67(3) (2016) 249-256. DOI: https://doi.org/10.3109/09637486.2016.1157140.

[36] R. Molinari, L. Constantini, A.M. Timperio, V. Lelli, F. Bonafaccia, G. Bonafaccia, N. Merendino, Tartary buckwheat malt as ingredient of gluten-free cookies, Journal Cereal Science 80 (2018) 37-43. DOI: https://doi.org/10.1016/j.jcs.2017.11.011.

[37] C.M. Mancebo, P. Rodriguez, M. Gómez, Assessing rice flour-starch-protein mixtures to produce gluten free sugar-snap cookies, LWT Food Science. Technology 67 (2016) 127-132. DOI: https://doi.org/10.1016/j.lwt.2015.11.045.

[38] R.A. Chávez-Santoscoy, J.A. Gutiérrez-Uribe, S O. Serna-Saldivar, and E. Perez-Carrillo, Production of maize tortillas and cookies from nixtamalized flour enriched with anthocyanins, flavonoids and saponins extracted from black bean (Phaseolus vulgaris) seed coats, Food Chemistry 192(1) (2016) 90-97.DOI:

https://doi.org/10.1016/j.foodchem.2015.06.113.

[39] K.N. Jan, P.S. Panesar, S. Singh, Optimization of antioxidant activity, textural and sensory characteristics of gluten-free cookies made from whole indian quinoa flour, LWT Food Science and Technology 93 (4) (2018) 573-582. DOI: https://doi.org/10.1016/j.lwt.2018.04.013.

[40] G. Giuberti, A. Marti, P. Fortunati, A. Gallo, Gluten free rice cookies with resistant starch ingredients from modified waxy rice starches: Nutritional aspects and textural characteristics, Journal Cereal Science $76 \quad$ (2017) 157-164. DOI: https://doi.org/10.1016/j.jcs.2017.06.008.

[41] C.W. Simons, C. Hall, Consumer acceptability of gluten-free cookies containing raw cooked and germinated pinto bean flours, Food Science Nutrition 6 (2017) 277-284. DOI: https://doi.org/10.1002/fsn3.531.

[42] R. Barlina, P. Pasang, D. Torar, D.A.N. Steivie, Substitution of Sago Flour and VirginCoconut Oil (VCO ) in Processing of Biscuits, Buletin Palma 13(1) (2012) 54-59.

[43] D. Ratnasari, Y. Yunianta, Pengaruh tepung kacang hijau, tepung labu kuning, margarin terhadap fisikokima dan organoleptik biskuit, Pangan dan Agroindustri 3(4) (2015). 1652-1661.

44] W. Yuliatmoko, D.I. Satyatama, Terigu dalam pembuatan cookies yang disuplementasi, Jurnal Matematika Sains dan Teknologi 13(2) (2012) 94106. 